\title{
Hva styrker verdigheten til kreftsyke kvinner som ønsker å dø hjemme?
}

Verdighetsbevarende omsorg er en viktig del av sykepleien til hjemmeboende kreftsyke kvinner i palliativ fase. For å sikre at kvinnene får behandling av høy kvalitet må sykehus og kommunehelsetjenesten samarbeide godt.

\section{Forfattere}

Katrine Staats

Ph.d.-kandidat

Institutt for global helse og samfunnsmedisin, Universitetet i Bergen

Ellen Karine Grov

Professor

Oslomet - storbyuniversitetet

Bettina Husebø

Professor

Det medisinsk-odontologiske fakultet, Universitetet i Bergen

Oscar Tranvåg

Postdoktor

Institutt for global helse og samfunnsmedisin, Universitetet i Bergen, Nasjonal

kompetansetjeneste for kvinnehelse, Oslo Universitetssykehus og Institutt for helse- og omsorgsvitskap, Høgskulen på Vestlandet

\begin{tabular}{l|l|l|} 
Pasientforløp Palliasjon $\quad$ verdighet & Samhandling
\end{tabular}

Sykepleien 2019 107(76713)(e-76713)

DOI: https://doi.org/10.4220/Sykepleiens.2019.76713

Hovedbudskap 
Artikkelen skrives ut fra ph.d.-prosjektet «Den verdige døden - verdighetsbevarende omsorg for hjemmeboende kreftsyke eldre kvinner». I artikkelen beskriver og diskuterer vi sentrale utfordringer og muligheter knyttet til helhetlig pasientforløp for pasienter som er i en palliativ fase, og som ønsker å dø hjemme.

\section{Målet med prosjektet}

Målet med ph.d.-prosjektet er å knytte forskning tettere opp mot de helse- og omsorgsutfordringer som innbyggerne møter i sin hverdag i kommune-Norge. Kunnskap om hvilke faktorer som fremmer en verdig avslutning på livet er sparsom. I ph.d.prosjektet undersøker og dokumenterer vi hvilke faktorer som fremmer en verdig avslutning på livet for hjemmeboende kreftsyke kvinner over 65 år.

Kilde:

https://app.cristin.no/projects/show.jsf? $\underline{\mathrm{id}=631954}$

Samhandling mellom nivåene i helsetjenesten innebærer komplekse samspill. Fragmentering av helsetjenesten kan føre til at oppmerksomheten rettes fra pasientene til andre viktige arbeidsoppgaver, noe som kan krenke pasientens verdighet. Nasjonale politiske føringer og faglige råd legger vekt på å etablere en pasientnær tilnærming. For at pasienter i palliativ fase skal føle seg sett og hørt i sine ønsker mot livets slutt, er det avgjørende å sikre gode rutiner for samhandling mellom tjenestenivåene.

\section{三 «Det legges nå opp til at pasienter skal pleies hjemme så lenge som mulig.»}


Helse- og omsorgsmyndighetene ønsker å styrke kvaliteten og kapasiteten i den kommunale palliative omsorgstjenesten, slik at flere kan få en verdig død hjemme. Det legges nå opp til at pasienter skal pleies hjemme så lenge som mulig, og nye krav om økt kompetanse er en utfordring sykepleiere møter daglig.

\section{Skal utvikle ny kunnskap}

Pasienter som er i palliativ fase, har komplekse behov (1) som skal ivaretas gjennom aktiv behandling, pleie og omsorg (2). Ph.d.-prosjektet «Den verdige døden verdighetsbevarende omsorg for hjemmeboende kreftsyke eldre kvinner» (4) har til hensikt å utvikle ny kunnskap som kan anvendes i den palliative omsorgstjenesten i kommunene. Prosjektets mål er å identifisere og beskrive faktorer som henholdsvis fremmer og krenker verdigheten til eldre, hjemmeboende kvinner med kreftsykdom når livet går mot slutten. Vi vil drøfte sentrale utfordringer og muligheter knyttet til helhetlig pasientforløp for pasienter i palliativ fase som ønsker å dø hjemme i lys av Davina Allens Translation Mobilisation Therory (TMT).

\section{Verdighetsbevarende omsorg}

Verdighetsbevarende omsorg er forankret i et menneskesyn som anerkjenner at hvert enkelt menneske, i kraft av å være menneske, har en iboende verdighet (verdighet, som noe som hører mennesket til), og samtidig anerkjenner at hvert enkelt menneske har behov for å oppleve verdighet i sin hverdag (verdighet som opplevelse). Dette innebærer humanistiske, etiske, faglige, juridiske og politiske fordringer i alle former for mellommenneskelig samhandling. (3. s.93107)

\section{Helhetlig pasientforløp}


Det stilles store krav til sykepleiere når de skal planlegge og utøve sykepleie til pasienter i palliativ fase, noe som innebærer komplekse observasjoner og tiltak. I denne prosessen må sykepleiere blant annet ha god kompetanse innen tverrfaglig samarbeid. Et pasientforløp involverer gjerne en rekke tjenesteytere, som for eksempel lege, hjemmesykepleier, ergoterapeut, fysioterapeut og kreftkoordinator, og behovet for å samarbeide og koordinere tjenestene blir svært tydelig sett fra pasientens ståsted (5, s. 16).

\section{三 «Fragmentering av helsetjenesten er uheldig for den enkelte pasient i palliativ fase.»}

Fragmentering av helsetjenesten er uheldig for den enkelte pasienten i palliativ fase. Flere politiske dokumenter som «Sammen mot kreft: Nasjonal kreftstrategi 2013-2017» (6) og «Nasjonalt handlingsprogram for palliasjon i kreftomsorgen» (7) fremhever viktigheten av et helhetlig pasientforløp og verdien av pasientsentrert omsorg.

En viktig målsetting er også å forebygge at det utvikler seg store forskjeller i tjenestetilbudet som gis her til lands, og å sikre denne pasientgruppen et helhetlig pasientforløp. Handlingsprogrammet beskriver videre at kulturen innen norsk, palliativ omsorg nettopp kjennetegnes ved helhetlig tilnærming til den alvorlig syke og døende, og til hans/hennes pårørende.

Koordinerte tjenester og systematisk samarbeid på tvers av spesialisthelsetjenesten og kommunehelsetjenesten beskrives som viktige faktorer for å optimalisere samarbeidet. Men, i praksis, er det slik vi oppfatter og erfarer samhandlingen rundt våre pasienter i den palliative fasen?

\section{Pasientmedvirkning}


I den senere tiden har man i helsesektoren hatt økt oppmerksomhet på pasientperspektivet; pasienten blir i økende grad oppfattet som en viktig samarbeidspartner. Som et resultat av den offentlige utredningen «På liv og død - Palliasjon til alvorlig syke og døende» (8) kom Helsedirektoratet (9) nylig med nasjonale faglige råd som blant annet fremhever alvorlig syke og døende pasienters rett til medvirkning. Pasientmedvirkning er i tråd med pasient- og brukerrettighetsloven (9) og innebærer viktige etiske hensyn knyttet til målet om å fremme en verdig død.

\section{Utfordringer ved utskrivelse}

I St.meld. nr. 47 (2) «Samhandlingsreformen - Rett behandling - på rett sted - til rett tid», understrekes det at kommunene har ansvaret for å gi helsehjelp og pleie- og omsorgstjenester til pasienter som er definert som utskrivningsklare fra sykehuset.

Etter at samhandlingsreformen trådte i kraft i 2012, har kortere liggetid på sykehus, med tidligere utskriving av pasientene, økt behovet for komplekse helse- og omsorgstjenester i kommunene.

Å imøtekomme kravet om kortere liggetid fordrer tilgang til kvalifisert helsepersonell til enhver tid, slik at både pasienter og pårørende skal føle seg trygge ved utskrivelse (6). Riksrevisjonen (11) understreker at på tross av de store endringene i helsetjenesten etter at samhandlingsreformen ble innført, finnes det lite kunnskap om kvaliteten på tjenestene til pasientene som skrives ut til kommunene.

\section{三 «For tidlig utskrivning og mangler ved det kommunale tjenestetilbudet er to viktige årsaker til at flere pasienter blir reinnlagt i sykehus.»}


For tidlig utskriving og mangler ved det kommunale tjenestetilbudet er to viktige årsaker til at flere pasienter blir reinnlagt på sykehus. Kommunene mottar nå pasienter som har fått behandling på sykehus - på et tidligere tidspunkt enn før, men kommunene har i liten grad styrket sin kapasitet og kompetanse. Riksrevisjonen hevder at samarbeidet knyttet til pasienter med behov for tjenester fra både primær- og spesialisthelsetjenesten ikke er godt nok (11), noe som i stor grad berører pasienter med behov for palliativ omsorg.

\section{Arenaer for samarbeid}

Sykepleiere i spesialisthelsetjenesten og primærhelsetjenesten synes å ha forskjellige kriterier for når de mener pasientene er utskrivningsklare. Sykepleiere i sykehus, som ikke kjenner arbeidskulturen i hjemmetjenesten, kan fra sitt ståsted synes å være for lite opptatt av det helhetlige og langsiktige pasientforløpet som må planlegges for å kunne møte den enkelte pasientens behov etter utskrivelse. Begrenset forståelse for det viktige arbeidet med å kartlegge pasientens videre behov og ønsker kan dermed svekkes (12). Problemstillinger knyttet til forskjellige arbeidskulturer er viktig å løfte frem, slik at én kan skape forbedrede samarbeidsarenaer for sykepleiere som arbeider på sykehus og i den kommunale helsetjenesten.

Samarbeidsmøter kan for eksempel bidra til å utvikle felles forståelse og rutiner for pasienter som blir definert som utskrivningsklare (12).

\section{Sårbare skrives ut}


I forskningsprosjektet «Den verdige døden verdighetsbevarende omsorg for hjemmeboende kreftsyke eldre kvinner» er deltakerne kvinner, eldre enn 65 år, som har kreftsykdom. Council for International Organizations of Medical Sciences (CIOMS) definerer disse som sårbare pasienter (13). Groene og medarbeidere (14) fant i sin studie en rekke utfordringer knyttet til sårbare pasienter som skrives ut fra sykehus.

\section{三 «Ofte er det pasienten selv som har sykehusets skriftlige eller muntlige rapport med seg hjem.»}

Ofte er det pasienten selv som har sykehusets skriftlige eller muntlige rapport med seg hjem. Slike samhandlingsrutiner fører ofte til uheldige situasjoner som setter pasientsikkerheten på prøve (14). For å sikre god og sikker flyt av pasientinformasjon på tvers av nivåer ble det i 2005 innført et system med elektroniske meldinger i Norge mellom spesialisthelsetjenesten og kommunehelsetjenesten (15).

I tillegg til meldingsutvekslingen mellom helsetjenestenivåene har man erfart at systemet bidrar til å sette i gang refleksjon hos sykepleiere samt øke sykepleiernes oppmerksomhet rundt pasientens behov.

Studien til Hellesø og medarbeidere (15) konkluderer med at digitalisering av pasientinformasjon har økt kvaliteten på pasientforløpene. Man ser likevel at epost og telefon er mye brukt for å kvalitetssikre helhetlige pasientforløp. Grunnen til at e-post og telefon brukes, er at de forskjellige nivåene i helsetjenesten ser ut til å benytte seg av datasystemer som ikke alltid er forenlige. I tillegg er det ikke alle nyanser og beskrivelser av pasientsituasjonen som lar seg uttrykke i et standardskjema (16).

\section{Brudd i samhandlingen}


Å opprettholde et helhetlig perspektiv på pasienten og deres pasientforløp er utfordrende. Utfordringer kan oppstå på grunn av manglende flyt i forløpene, og fragmenterte helsetjenester skaper brudd i samhandlingen (17). Pasientene beskriver slike brudd som synlige problemstillinger, og situasjonen kan få et annet søkelys enn mot pasienten - og dermed krenke pasientens verdighet.

\section{三 «Pasientene hevder at helsepersonell er altfor opptatt av sine egne profesjoner og arbeidsområder.»}

Pasientene hevder at helsepersonell er altfor opptatt av sine egne profesjoner og arbeidsområder, og at det er lite kommunikasjon og samhandling mellom forvaltningsnivåene (18).

\section{Usynlig arbeid}

Utskrivningsplanlegging fra sykehuset innebærer et komplekst samspill, og ved utskrivingen foregår mye av det vi kan kalle «usynlig arbeid» (5, s. 240). Mye av arbeidet knyttet til utskrivningsprosessen foregår med andre ord «på siden av» eller «i tillegg til» de formelle retningslinjene og defineres som «usynlig merarbeid» av Allen (19). Kirchhoff (19) anvender begrepet «usynlig arbeid» om arbeid som sykepleiere selv omtaler som upassende arbeid, som verken er ønsket eller forventet av organisasjonen de arbeider for. Dette «usynlige arbeidet» reiser spørsmål om hva som kan skje dersom det forventes at retningslinjene skal følges slavisk (4). Men hva er nå dette «usynlige arbeidet» som preger hverdagen til mange helsearbeidere, og som bidrar til å hemme implementeringen av helhetlige og fleksible pasientforløp?

\section{Økt forståelse}


I arbeidet med å utvikle en teoretisk forståelse for hva et helhetlig pasientforløp innebærer - og hva sykepleieres «usynlige arbeid» i denne sammenhengen handler om, kan det teoretiske rammeverket Translation Mobilisation Theory (TMT) (21) være et godt verktøy. Davina Allen formulerte denne sosiologiske teorien for å forklare hvordan felles aktiviteter og handlinger kan utvikle seg i komplekse situasjoner.

I palliative pasientforløp som krever god samhandling mellom sykehus og den kommunale hjemmetjenesten, kan situasjonen være preget av uforutsigbarhet, kompleksitet og oversiktlighet. Allen (22) hevder at ved å beskrive sykepleieres organiseringsarbeid, kan vi lettere forstå bredden i sykepleien. Arbeidet som gjøres av sykepleiere defineres her som transformerende mobilisering, som betyr «å omforme og å gi retning» og fremhever alle prosessene sykepleiere er en del av. Teorien beskriver også hvordan sykepleierne bidrar til å binde sammen de ulike delprosessene (22). Pasienter i palliativ fase som ønsker å reise fra sykehuset og til hjemmet sitt, defineres hos Allen som objektet i forløpet (objektformasjon), mens translasjon er en mekanisme hvor de forskjellige leddene i samhandlingsprosessen tilpasses objektet.

\section{三 «Det kreves en rekke aktiviteter og handlinger for å oppnå god samhandling i et palliativt forløp.»}


Det vil si at pasienten må bli sett med et holistisk perspektiv, og at det må utvikles en felles forståelse av pasienten og dennes situasjon (22). Det kreves en rekke aktiviteter og handlinger for å oppnå god samhandling i et palliativt forløp. Som nevnt er mange av disse handlingene «usynlige», og sykepleiere utfører en stor del av oppgavene gjennom pasientforløpet (4). Allen (22) kaller disse aktivitetene for artikulering. Det vil si aktiviteter som brukes for å knytte sammen de forskjellige leddene i et pasientforløp.

Et eksempel på en slik aktivitet kan være elektroniske meldinger som benyttes av sykepleiere $\mathrm{i}$ spesialisthelsetjenesten og i den kommunale helsetjenesten, for å samhandle og planlegge en utskrivelse av en pasient i palliativ fase. En annen mekanisme omhandler helsepersonells evne til å reflektere over egne handlinger og andre profesjoners handlinger - gjennom samhandlingsprosessen. Denne mekanismen defineres som refleksiv monitorering og kan bidra til å fremme kvaliteten i gjennomføringen av det helhetlige palliative pasientforløpet.

Avslutningsvis vektlegger Allen i sin teori verdien av å gi mening til - som oppstår når forskjellige profesjoner i pasientforløpet sammen makter å skape mening og forutsigbarhet i pasientsituasjonen. Når de ulike profesjonene som deltar i samhandlingen, mestrer de fem ovennevnte utfordringene, vil det skapes en felles forståelse av den gjensidige avhengigheten som eksisterer mellom profesjonene, og fremme samhandling av høy kvalitet til det beste for den enkelte pasienten (22).

\section{Verdighetsbevarende omsorg}


For å sikre behandling, pleie og omsorg av høy kvalitet til pasienter i palliativ fase som ønsker å tilbringe sin siste levetid hjemme, er det avgjørende å etablere god kommunikasjon med pasienten og de pårørende om deres ønsker, behov og forutsetninger (9). Avklarende samtaler med alvorlig syke pasienter bør gjøres på sykehus i et relativt tidlig stadium, slik at planleggingen rundt utskrivelsen kan skje på best mulig måte.

I prosjektet «Den verdige døden verdighetsbevarende omsorg for hjemmeboende kreftsyke eldre kvinner» er det en målsetting å oppnå $ø$ kt kunnskap om forberedende samtaler, som kan anvendes av de palliative omsorgstjenestene i kommunene. Vi undersøker og beskriver erfaringer og perspektiver hos pasienter, pårørende, fastleger og kreftsykepleiere i kommunehelsetjenesten. Det er fire sentrale kilder, som fra sine ulike ståsteder vil kunne belyse sentrale utfordringer og muligheter i den tverrfaglige og tverrsektorielle samhandlingen mellom spesialisthelsetjenesten og kommunehelsetjenesten.

Nasjonale politiske føringer og faglige råd legger vekt på å etablere en pasientnær tilnærming mellom helsepersonell og pasienter. En sykepleietjeneste med høy kompetanse er viktig for å styrke målet.

Sykepleierens viktige rolle vil bli enda tydeligere om også sykepleiernes «usynlig arbeid» blir synliggjort.

Prosjektet vil kunne bidra med beskrivelser av hva som betraktes som «usynlig arbeid» fra ulike profesjoner. Videre kan funn fra studien også bidra til økt kunnskap knyttet til begrepet verdighetsbevarende omsorg, tidligere kjent fra forskning innen omsorg for personer med demens (23).

\section{«Vi anser verdighetsbevarende omsorg som en viktig dimensjon i utøvelsen av sykepleie til pasienter i palliativ fase.»}


Vi anser verdighetsbevarende omsorg som en viktig dimensjon i utøvelsen av sykepleie til pasienter i

palliativ fase som ønsker å tilbringe sin siste levetid hjemme. Å utvikle ny kunnskap om hva som bidrar til å bevare deres verdighet, og hva som bidrar til å krenke deres verdighet, bør etter vårt syn være en sentral dimensjon i det kunnskapsgrunnlaget som kan anvendes i samhandlingen mellom spesialisthelsetjenesten og kommunehelsetjenesten. Da kan en samarbeidende helsetjeneste etter vår oppfatning bli bedre i stand til å ivareta pasientenes rett til en verdig død (24) - i samsvar med «Yrkesetiske retningslinjer for sykepleiere» (25).

\section{Referanser}

1. Murray SA, Kendall M, Boyd K, Sheikh A. Illness trajectories and palliative care. BMJ. 2005;330(7498): 1007. DOI: 10.1136/bmj.330.7498.1007

2. St.meld. nr. 47 (2008-2009).

Samhandlingsreformen. Rett behandling - på rett sted - til rett tid. Oslo: Helse- og omsorgsdepartementet; 2009.

3. Tranvåg O. Verdighetsbevarende omsorg for personer med demens. I: Hillestad E, Tessem J, red. Frivillighetens kraft. Organisering av frivillig innsats i eldreomsorgen. Bergen: Fagbokforlaget; 2018. s. 93107.

4. Extrastiftelsen. Den verdige døden. Oslo:

Exstrastiftelsen; 2019. Tilgjengelig fra:

https://www.extrastiftelsen.no/prosjekter/den-verdigedoden/ (nedlastet 07.05.2019).

5. Hellesø R, Melby L. Forhandlinger og samspill i utskrivningsplanleggingen av pasienter på sykehus. I: Tjora A, Melby L, red. Samhandling for helse. Kunnskap, kommunikasjon og teknologi i helsetjenesten. Oslo: Gyldendal Norsk Forlag; 2013. s. 222-42. 
6. Helse- og omsorgsdepartementet. Sammen mot kreft: Nasjonal kreftstrategi 2013-2017. Oslo: Helseog omsorgsdepartementet; 2013.

7. Helsedirektoratet. Nasjonalt handlingsprogram for palliasjon i kreftomsorgen. Oslo: Helsedirektoratet; 2015.

8. NOU 2017: 16. På liv og død - Palliasjon til alvorlig syke og døende. Oslo: Helse- og omsorgsdepartementet: 2017.

9. Helsedirektoratet. Nasjonale faglige råd for lindrende behandling i livets sluttfase. Oslo: Helsedirektoratet; 2018.

10. Lov 2. juli 1999 nr. 63 om pasient- og brukerrettigheter (pasient- og brukerrettighetsloven). Oslo: Helse- og omsorgsdepartementet; 2001.

11. Riksrevisjonen. Riksrevisjonens undersøkelse av ressursutnyttelse og kvalitet i helsetjenesten etter innføringen av samhandlingsreformen. dokument 3:5. Oslo: Riksrevisjonen; 2016.

12. Hellesø R, Fagermoen MS. Cultural diversity between hospital and community nurses. implications for continuity of care. Int J Integr Care. 2010 Jan-Mar.

13. Council for International Organizations of Medical Sciences. International ethical guidelines for biomedical research involving human subjects.

Geneva: CIOMS; 2002.

14. Groene R, Orrego O, Suñol C, Barach RP, Groene O. «It's like two worlds apart»: an analysis of vulnerable patient handover practices at discharge from hospital. BMJ Quality \& Safety. 2012;21(Suppl 1), i67. DOI: 10.1136/bmjqs-2012-001174 
15. Hellesø R, Melby L, Brattheim BJ, Toussaint PJ. Exchange of information between hospital and home health care: A longitudinal perspective. Stud Health Technol Inform. 2016;225:349-53. DOI: 10.3233/9781-61499-658-3-349

16. Olsen RM, Hellzèn O, Enmarker I. Nurses' information exchange during older patient transfer: prevalence and associations with patient and transfer characteristics. Int J Integr Care. 2013;13(1). DOI: 10.5334/ijic.879

17. Sheaff R, Halliday J, Byng R, Øvretveit J, Exworthy M, Peckham S, Asthana S. Bridging the discursive gap between lay and medical discourse in care coordination. Sociology of Health \& Illness. 2017;39(7), 1019-34. DOI: 10.1111/1467-9566.12553

18. Den Herder-van Der Eerden M, Hasselaar J, Payne S, Varey S, Schwabe S, Radbruch L, Groot M. How continuity of care is experienced within the context of integrated palliative care: A qualitative study with patients and family caregivers in five European countries. Palliat Med. 2017;31(10): 946-55. DOI: $10.1177 / 0269216317697898$

19. Allen D. The invisible work of nurses: Hospitals, organisation and healthcare. London: Routledge; 2014.

20. Kirchhoff JW. De skjulte tjenestene - om uønsket atferd i offentlige organisasjoner. Karlstad: Karlstads universitet; 2010.

21. Allen D, May C. Organizing practice and practicing organization: an outline of translational mobilization theory. SAGE Open. 2017; 7(2). DOI: 10.1177/2158244017707993

22. Allen D. Analysing healthcare coordination using translational mobilization. J Health Organ Manag. 2018; 32(3): 358-73. DOI: 10.1108/JHOM-05-20170116; 
23. Tranvåg O. Dignity-preserving care for persons

living with dementia. (Doktoravhandling.) Bergen:

Universitetet i Bergen; 2015.

24. Forskrift 01.01.2011 om en verdig eldreomsorg.

(Verdighetsgarantien). Oslo: Helse- og

omsorgsdepartementet; 2010.

25. Norsk Sykepleierforbund. Yrkesetiske

retningslinjer for sykepleiere. Oslo: Norsk

Sykepleierforbund; 2011. Tilgjengelig fra:

https://www.nsf.no/vis-

artikkel/2193841/17102/Yrkesetiske-retningslinjer

(nedlastet 03.05.2019). 